\title{
Competition Policy within the Coordinated and Hierarchical Market Tradition: The Case of Germany and France
}

Citation for published version (APA):

Bos, I. (2019). Competition Policy within the Coordinated and Hierarchical Market Tradition: The Case of Germany and France. Maastricht University, Graduate School of Business and Economics. GSBE Research Memoranda No. 018 https://doi.org/10.26481/umagsb.2019018

Document status and date:

Published: 20/06/2019

DOI:

10.26481/umagsb.2019018

Document Version:

Publisher's PDF, also known as Version of record

\section{Please check the document version of this publication:}

- A submitted manuscript is the version of the article upon submission and before peer-review. There can be important differences between the submitted version and the official published version of record.

People interested in the research are advised to contact the author for the final version of the publication, or visit the DOI to the publisher's website.

- The final author version and the galley proof are versions of the publication after peer review.

- The final published version features the final layout of the paper including the volume, issue and page numbers.

Link to publication

\footnotetext{
General rights rights.

- You may freely distribute the URL identifying the publication in the public portal. please follow below link for the End User Agreement:

www.umlib.nl/taverne-license

Take down policy

If you believe that this document breaches copyright please contact us at:

repository@maastrichtuniversity.nl

providing details and we will investigate your claim.
}

Copyright and moral rights for the publications made accessible in the public portal are retained by the authors and/or other copyright owners and it is a condition of accessing publications that users recognise and abide by the legal requirements associated with these

- Users may download and print one copy of any publication from the public portal for the purpose of private study or research.

- You may not further distribute the material or use it for any profit-making activity or commercial gain

If the publication is distributed under the terms of Article $25 \mathrm{fa}$ of the Dutch Copyright Act, indicated by the "Taverne" license above, 
Maastricht University

Iwan Bos

Competition Policy within the Coordinated and Hierarchical Market Tradition: The Case of Germany and France

RM/19/018

\section{GSBE}

Maastricht University School of Business and Economics

Graduate School of Business and Economics

P.O Box 616

NL- 6200 MD Maastricht

The Netherlands 


\title{
Competition Policy
}

within

the Coordinated and Hierarchical Market Tradition:

\author{
The Case of Germany and France ${ }^{1}$
}

by

Iwan Bos ${ }^{2}$

(June 2019)

"Beyond differences and geographical boundaries, there lies a common interest" (Jean Monnet)

\section{Introduction}

In the spring of 1950 , the French foreign minister Robert Schuman stated that: ${ }^{3}$

"Europe will not be made all at once, or according to a single plan. It will be built through concrete achievements which first create a de facto solidarity. The coming together of the nations of Europe requires the elimination of the age-old opposition of France and Germany. Any action taken must in the first place concern these two countries."

\footnotetext{
${ }^{1}$ I acknowledge the valuable comments of Igor van Loo. This paper is written as part of the research project What Good Markets Are Good For and made possible through the support of a grant from Templeton World Charity Foundation, Inc.. The opinions expressed in this publication are mine alone and do not necessarily reflect the views of Templeton World Charity Foundation, Inc..

${ }^{2}$ Department of Organisation, Strategy and Entrepreneurship, School of Business and Economics, Maastricht University. E-mail: i.bos@maastrichtuniversity.nl.

${ }^{3}$ May 9, 1950. Full text is available at: https://europa.eu.
} 
In the same speech, now known as the Schuman declaration, Schuman proposed setting up a supranational organisation to pool European coal and steel production. ${ }^{4}$ About a year later, the establishment of the European Coal and Steel Community (ECSC) was among the first concrete achievements towards building a united Europe. ${ }^{5}$

The ECSC Treaty contained two explicit competition provisions; both of which foreshadowed the European competition policy of today. ${ }^{6}$ These competition rules were poorly enforced, however, which was not least due to the lack of independence of the ECSC High Authority; an executive commission in charge of the implementation of the Treaty's goals. Although the member states clearly agreed on the High Authority's sovereignty, the political reality at the time was one of continuous interference by primarily France and Germany. ${ }^{7}$ This naturally called for a different competition policy design for the European Economic Community $(E E C)$. Some years later, under heavy influence of the German-driven ordoliberalism doctrine, a strong European competition policy framework was established with an independent supranational competition authority. ${ }^{8}$

The ECSC and EEC competition policy experience can be embedded in recent discussions on different types of capitalist systems, particularly the

\footnotetext{
${ }^{4}$ Although the focus was on French and German production, Schuman was explicit about the possibility for other European countries to join the proposed organisation.

${ }^{5}$ This organisation was the outcome of a Treaty signed by Belgium, France, Germany, Italy, Luxembourg and the Netherlands in Paris on April 18, 1951.

${ }^{6}$ The ECSC Treaty contained both a cartel prohibition and merger provisions, see Chapter VI of this Treaty Agreements and concentrations, Articles 65 and 66.

${ }^{7}$ Article 9 of the ECSC Treaty states: "The members of the High Authority shall exercise their functions in complete independence, in the general interest of the Community. In the fulfillment of their duties, they shall neither solicit nor accept instructions from any government or from any organization. They will abstain from all conduct incompatible with the supranational character of their functions." and "Each member state agrees to respect this supranational character and to make no effort to influence the members of the High Authority in the execution of their duties."

${ }^{8}$ This framework is based on the Treaty of Rome that was signed on March 25, 1957 and came into force on January 1, 1958. A few years later, Regulation $17 / 62$ arranged the implementation of the horizontal restraints and abuse of dominance provisions (Articles 85 and 86 of the EEC Treaty) and granted substantial power to the European Commission as competition law enforcer.
} 
coordinated and hierarchical market models. ${ }^{9}$ The ECSC case fits naturally within the hierarchical market tradition, for example. In the hierarchical archetype, competition policy is characterised by weak enforcement as well as close ties between big business and the political system. ${ }^{10}$ Additional, complementary, traits include the dominance of family and multinational corporations as well as the relatively weak position of workers. ${ }^{11}$ By contrast, the EEC case reflects the ordoliberal philosophy and is therefore primarily compatible with the coordinated market tradition. In the coordinated archetype, competition policy is characterised by strong enforcement and a clear dividing line between the private and the public sphere. More specifically, the aim is to safeguard the competitive process, while reducing concentrations of market and political power.

In this paper, we show that German and French competition policy can also be placed within the coordinated and hierarchical market tradition. Akin to the European story, both originate from a mainly hierarchical based framework and evolved towards a system compatible with the coordinated market model. At the same time, however, we argue that this transformation to date has been incomplete in the sense that both competition policies still contain some hierarchical elements. Specifically, both the German and the French economic ministries can legally interfere with merger cases and, in the name of public interest, overrule a blocking decision by the national competition authority. Thus, and despite the dominance of the ordoliberal doctrine, both the German and French states are not (yet) out of sight when it comes to shaping industry structures.

\footnotetext{
${ }^{9}$ See, for instance, Whitley (1999), Hall and Soskice (2001), Schneider (2009), Schneider and Soskice (2009). Akin to the varieties in capitalism literature, Poli (1915) provides a detailed discussion on why competition policies may differ across free market based societies.

${ }^{10}$ See, in particular, Schneider and Soskice (2009).

${ }^{11}$ See Schneider (2009).
} 
The next section provides a brief history of German competition policy and discusses the transformation from a hierarchical based system to the coordinated based framework of today. Section 3 takes a similar approach to discuss the French case. Section 4 concludes.

\section{The German Case}

\subsection{A Brief History of German Competition Policy}

The first German competition law was passed during the Weimar period. This Verordnung gegen Missbrauch wirtschaftlicher Machtstellungen came into force in 1923 and was directed against abuse of economic power by (groups of) firms. ${ }^{12}$ It did not contain a prohibition of anticompetitive combinations such as cartels, but allowed collusive agreements to be declared null and void when contractual terms were the consequence of monopolistic conduct by one or more members. ${ }^{13}$ The ordinance was enforced by both the Reich Minister of Economics and a newly established Kartellgericht; a cartel court that effectively operated as an administrative agency. ${ }^{14}$ This court was not very efficacious, however, and, if anything, enhanced the overall positive image of cartels in the Germany of that time. ${ }^{15}$

As the 1923 cartel ordinance was a control measure and not a prohibition, there was a natural connection with the preceding enforcement system. Since the German unification in $1871 \mathrm{AD}$, cartel agreements were commonly assessed like any other contract under the German civil code. In this context, the main issue was whether the cartel contract must be considered contrary to good morals and customs (contra bonos mores et decorum). In the last few decades of the $19^{\text {th }}$ century, the dominant view

\footnotetext{
12 This Kartellverordnung was enacted on November 2, 1923 and is, in fact, considered the first actual competition law in Europe.

${ }^{13}$ It also contained a provision on (un)reasonable pricing. See Neumann (1998). See Schwarz (1957) for a detailed discussion and English translation of this ordinance.

${ }^{14}$ Schwarz (1957) provides a detailed discussion of the division of enforcement tasks during the Weimar republic.

${ }^{15}$ Cartels were viewed effective and ethical organizational forms by many. See Gerber (1998, Chapters 4 \& 5).
} 
was that such organisations should be permitted or even encouraged, in particular during economic depressions: ${ }^{16}$

"...it was not contra bonos mores for business men belonging to a branch of industry which is suffering from a depression to get together and enter into agreements regulating the ways and means of operating their industry with a view to promoting recovery. On the contrary such course of action would seem to be incumbent upon prudent business men."

In a similar spirit, cartel contracts were widely viewed as an effective means to avoid ruinous competition. This was made explicit in a case concerning wood pulp manufacturers in 1897. A defecting member sued the cartel, the Sächsischen Holzstoff-Fabrikanten-Verband, for limiting its freedom of trade (Gewerbefreiheit). ${ }^{17}$ The German Supreme Court (Reichsgericht) took the side of the conspirators, however, by arguing that the cartel did not actually harm the public interest or individual freedom. The Reichsgericht thus choose freedom of contract over freedom of trade. ${ }^{18}$ It further reasoned that: ${ }^{19}$

"...it cannot be generally considered contrary to the public welfare for producers or manufacturers to combine with a view to preventing the consequent slump in prices. On the contrary, when prices continue to be so low that business men are threatened with ruin, combination is not merely a legitimate means of self-preservation but also serves the public interest."

This wood pulp decision was taken to mean that cartels should, in principle, be considered legal.

\footnotetext{
${ }^{16}$ Quote by Wolff (1935) cited in Martin (2010).

${ }^{17}$ The core of the cartel agreement was to sell exclusively through a joint sales agency and non-abiding members were obliged to pay a fine. The defecting cartel participant sold its wood pulp directly to several paper producers.

${ }^{18}$ As stated by Neumann (1998): "...since freedom of business activity, according to the view of the Court, is deemed to encompass freedom to enter contracts which regulate prices in particular industries."

${ }^{19}$ B. v. den Sächsischen Holzstoff-Fabrikanten-Verband, Reichsgericht, February 4, 1897, 38 R.G.Z. 155 cited in Schwarz (1957). This argumentation by the former German Supreme Court confirmed the reasoning by the Bavarian appeal court about a decade earlier. In Oberstes Landesgericht Bavaria, April 7, 1888, Entsch. des Ob. L. G. 12, 67, this court argued: "... when prices are for a long time so low that financial ruin threatens the producers, their combination appears to be not merely a legitimate means of self-preservation, but also a measure serving the interests of society." Citation taken from Martin (2010).
} 
After a brief intermezzo in the years following the 1923 ordinance, the legal acceptance of cartels was further enhanced when the Nazi regime came to power in 1933. A few years prior, an ordinance to meet financial, economic and social emergencies was already enacted. This ordinance strengthened government involvement by enabling the economics ministry to directly interfere with cartel agreements. ${ }^{20}$ In 1933, the so-called Zwangkartellgesetz was passed; a decree that authorized the Reich Minister of Economics to virtually force firms into cartels in any industry. Not surprisingly, many industries got cartelized in the ensuing years. ${ }^{21}$ By the end of the 1930s, cartels were widespread and effectively agencies in a centrally controlled German economy.

In the decade following World War II, German competition policy came from the Allied Powers. Already at the Potsdam conference in 1945, there was great consensus that the power of German combinations should be diminished. Specifically, in paragraph 12 of the Report on the Tripartite Conference of Berlin it was stated that: ${ }^{22}$

"At the earliest practicable date, the German economy shall be decentralized for the purpose of eliminating the present excessive concentration of economic power as exemplified in particular by cartels, syndicates, trusts and other monopolistic arrangements."

This formed the foundation for the first cartel prohibition in German history. These types of organizations were declared unlawful through the so-called deconcentration laws of 1947, which also allowed for the decomposition of powerful companies into smaller units. ${ }^{23}$

After a series of drafts resulting from the complex political interactions between several parties, the Gesetz gegen Wettbewerbsbeschränkungen -

\footnotetext{
${ }^{20}$ See Schwarz (1957).

${ }^{21}$ See McGowan (2010).

${ }^{22}$ See the Report on the Tripartite Conference of Berlin - Final Typewritten Copy, August 2, 1945; available at: www.trumanlibrary.org.

${ }^{23}$ It should be noted that these laws were enacted by the Western allies and consequently only applied to their occupation territories.
} 
Kartellgesetz (GWB) was passed and came into effect on January 1 , 1958. ${ }^{24}$ Apart from some specific exemptions, the GWB outlawed horizontal anticompetitive conduct as well as abuse of dominance. More generally, this legislation contained many elements that can be found in the German competition policy of today.

Interestingly, it took quite a bit longer before a merger policy was introduced. Several business interest groups repeatedly and in some sense successfully put forth the argument that a stringent merger control would harm the competitive position of German firms in international markets. The opportunity for adopting a merger control regime arose after the Social Democrats and the Free Democrats took office in 1969. ${ }^{25}$ Together with the first major reform of the GWB that came into force in 1973 , a system of merger control was installed. ${ }^{26}$

The evolution of German competition law since 1973 is characterised by a series of reforms of the GWB. The third and fourth revision in 1976 and 1980 shaped the novel merger policy, whereas the fifth in 1989 focused on enhancing the position of modestly sized industries. Moreover, the number of sectors that were exempted from competition law prohibitions was slowly but surely reduced.

Overall, there has been a clear tendency to bring German competition policy more and more in line with its counterpart at the European level. The seventh amendment that was adopted in June 2005 is illustrative in this respect. This amendment centred on the application of European antitrust rules in the German jurisdiction and significantly reduced the scope of the national competition law. ${ }^{27}$ The ninth major reform entered

\footnotetext{
${ }^{24}$ The GWB was adopted on July 27, 1957. See Gerber (1998) for a detailed discussion of the (political) process leading to the adoption of the GWB.

25 These parties replaced the conservative government that had been dominating the political arena since World War II.

${ }^{26}$ Among others, the new GWB outlawed tacit collusion. See Neumann (1998).

27 See Klees (2006).
} 
into force on June 9, 2017. This last reform was enacted primarily to better cope with the digitalization trends in many markets and corresponding network effects.

\subsection{German Market Competition: From Hierarchy to Coordination?}

Together with some small countries like the Netherlands, Germany has had a long reputation for being a cartel's paradise. The brief description of German competition policy history confirms this picture up until the end of World War II. During the decade thereafter, however, the legal view on such anticompetitive combinations changed dramatically. In particular, the loose control measures from before the war were replaced by tight prohibitions. Ever since the late 1950s, German and European competition policy are very similar. ${ }^{28}$

As mentioned in the introduction, this development can be positioned within the hierarchical and coordinated market tradition. Arguably, German competition policy is primarily compatible with the hierarchical market model until the end of the Second World War. Till then the system was supportive of big business, for example, which in turn made it easier for the German state to steer industries in its preferred direction. The Zwangkartellgesetz of 1933 is perhaps most illustrative in this regard as it allowed the Nazi regime to effectively use its domestic industries as weapons of war.

The adoption of the first German competition act, the cartel ordinance of 1923 , is also consistent with this argument. Not only was the enforcement of this law for a large part in the hands of the economics ministry, it was not very effective either. For an important part, this was simply due to the refusal by the Reich Minister of Economics to apply the abuse provisions: ${ }^{29}$

\footnotetext{
${ }^{28}$ Somewhat symbolically, the first actual German cartel prohibition and EEC competition policy both came into force on the same date: January 1, 1958.

${ }^{29}$ See Gerber (1998, p. 129).
} 
"Decisions were rare and of little importance, primarily because these provisions could only be used by the economics minister, and he seldom chose to use it! To do so would have been inconsistent with the 'cooperative' arrangements between the ministry and the cartels that constituted the informal system for achieving compliance with the statute."

Finally, it is noteworthy that both banks and families were frequently among the dominant shareholders of large German corporations and consequently held key decision-making positions. ${ }^{30}$ This too is characteristic of the hierarchical nature of German market competition up until the Second World War. ${ }^{31}$

This radically changed during the decade thereafter, however, primarily under the pressure of the United States and the increasingly popular ordoliberal philosophy. From the late 1950s onwards, Germany has embraced a market competition model that is characterised by a strong competition law framework and an equally strong enforcement policy implemented by an independent competition authority, the Bundeskartellamt. Since the start, officials working for this authority have had little discretion in interpreting the new German competition law. ${ }^{32}$ Thus, there has been a clear switch in German competition policy history from a hierarchical based model to a coordinated based model. Indeed, the current policy framework is arguably quite close to the ordoliberal ideal, particularly regarding the combat of anticompetitive conduct.

When it comes to issues of industry structure, however, the competition statutes still contain some clear hierarchical elements. Specifically, Section 42 of the GWB arranges the so-called Ministerial Authorisation for industry

\footnotetext{
${ }^{30}$ See Resch (2005).

${ }^{31}$ On the importance of family ownership and management within the hierarchical market tradition, see Schneider (2009).

${ }^{32}$ As stated by Gerber (1998, p. 287): "Decisions were...made according to juridical principles and procedures... allowing individuals little opportunity to give special attention to particular defendants. Moreover, the personnel of the Federal Cartel Office are largely protected from...temptations...by the Beamten tradition, according to which such officials generally cannot be removed from office and normally remain in government service throughout their careers".
} 
concentrations. Among other things, this provision enables the economics ministry to clear a merger even after it has been blocked by the Bundeskartellamt. ${ }^{33}$ This may occur when the benefits of the concentration to society are considered to outweigh the costs. Examples of such an overriding public interest include the protection of jobs in economically weak regions and the safeguarding of energy supplies. ${ }^{34}$ Though to date this provision has been rarely applied, its presence does imply that in matters of industry structure the German state is still around the corner. ${ }^{35}$

\section{The French Case}

\subsection{A Brief History of French Competition Policy}

Competition policy in France can be traced back to at least the late 1700s $A D$. Not long after the awakening of the French Revolution, the National (Constituent) Assembly adopted the Loi Le Chapelier. ${ }^{36}$ The name of this law refers to one of its most prominent initiators, Deputy Isaac-René-Guy Le Chapelier, who considered associations and groups in principle incompatible with the spirit of the Revolution. Several organizations, such as the professional guilds and trade unions, were thought to defend their own collective interest rather than that of individuals or society as a whole and therefore declared illegal. This law also prohibited market participants to make agreements designed to set common prices. ${ }^{37}$

\footnotetext{
${ }^{33}$ The first part of (the English version of) Section 42 GWB states: "The Federal Minister for Economic Affairs and Energy will, upon application, authorise a concentration prohibited by the Bundeskartellamt if, in the individual case, the restraint of competition is outweighed by advantages to the economy as a whole resulting from the concentration, or if the concentration is justified by an overriding public interest."

${ }^{34}$ More examples can be found in Verloop and Landes (2003).

${ }^{35}$ About two handfuls of applications have been granted thus far. See, for example, the German Negotiated M\&A guide available at: www.ibanet.org.

${ }^{36}$ This law was passed on June 14, 1791.

${ }^{37}$ An English translation of the first part of Article 4 of the Chapelier Law (available at: http://chnm.gmu.edu/revolution/d/370/) states: "It is contrary to the principles of liberty and the Constitution for citizens with the same professions, arts, or trades to deliberate or make agreements among themselves designed to set prices for their industry or their labor. If such deliberations and agreements are concluded, whether accompanied by oath or not, they will be declared unconstitutional, prejudicial to liberty and the Declaration of the Rights of Man, and will be null and void."
} 
In 1810, under the regime of Napoléon Bonaparte, a new Code Pénal saw the light of day. The central part on competition was Article 419, which stated that: ${ }^{38}$

"Those who, by false or slanderous reports, purposely spread among the people; or by offering higher prices than those which were asked by the venders themselves; or by coalitions or combinations among the principal holders of the same kind of merchandize or provisions, tending to prevent such goods being sold at all, or being sold under a certain price; or by any fraudulent ways or means whatever, shall have effected the enhancement or reduction of the price of provisions or merchandize; or of the public securities and stocks, above or below the prices which would have been determined by the free and natural competition of trade; shall be punished with an imprisonment of not less than one month, nor more than one year, and a fine of from 500 to 10,000 francs. The offenders may, moreover, be placed, by sentence or judgment, under the superintendence of the high police, during not less than two years, nor more than five years."

Note that this provision is primarily directed at pricing practices and, in particular, prices not resulting from the free and natural competition of trade. This soon appeared to be a complex criterion to apply in actual cases and also by no means ruled out anticompetitive actions per se. Moreover, a body of case law developed throughout the $19^{\text {th }}$ century that distinguished between good and bad cartels. Good ones (bonnes unions) were defensive coalitions which attempted to stabilize the market, while avoiding ruinous competition resulting from excessive supply. By contrast, bad cartels (mauvaises unions) were offensive coalitions which attempted to limit competition through monopolistic conduct. Since relatively few agreements were considered bad, this law had less and less bite. Article 419 was ultimately amended in 1926, in part, to clarify that price collusion is illegal precisely when it has the purpose of creating profits that would not result from the natural play of demand and supply. ${ }^{39}$

\footnotetext{
${ }^{38}$ English translation of the original taken from www.napoleon-series.org. The other main competition rule, Article 412, was directed at anticompetitive conduct at auctions. See, for instance, Clement (1974).

${ }^{39}$ See Riesenfeld (1962) and Pace (2007).
} 
This revision did not lead to a stricter policy towards cartels, however. On the contrary, France increasingly and explicitly recognized this type of anticompetitive agreement as an effective means to control industries and to ensure economic stability. In fact, the French government even required them in some industries during the crisis of the $1930 \mathrm{~s} .{ }^{40}$

In World War II, the Vichy government additionally made extensive use of industry associations; some of which remained active in the immediate post-war period (e.g., in the coal and steel sector). After Germany signed a surrender at the Allied headquarters in the French city of Reims, France convincingly choose to follow such a state-led route to rebuild the country.

This planning-oriented approach manifested itself in at least three ways. First, the Commissariat Général du Plan was established; a planning board which was given the task to design plans to support the recovery of the French economy. The first board, led by Jean Monnet, addressed the urgent issue of how to allocate scarce resources right after the end of the Second World War. It further advocated the need for systematic and large-scale investments, particularly in six so-called priority sectors: coal, steel, electricity, cement, agricultural machinery and transportation. ${ }^{41}$ Second, there was a series of nationalization decrees, which effectively restricted competition in key sectors including aviation, insurance, banking, electricity and gas. ${ }^{42}$ Third, the government issued an ordinance in June 1945, which enabled the extensive use of price controls and wage freezes. ${ }^{43}$

The 1945 ordinance additionally prohibited a collection of what was referred to as illicit pricing practices, which included refusals to deal and several forms of price discrimination. ${ }^{44}$ Combined with a series of

\footnotetext{
${ }^{40}$ See OECD (2003) and Riesenfeld (1960), which also provides several concrete examples.

${ }^{41}$ See Djelic (2001).

${ }^{42}$ See Riesenfeld (1960) and Djelic (2001). This increased state-control included well-known companies such as Air France, Renault and Crédit Lyonnais.

43 Ordinance No. 45-1483.

${ }^{44}$ See, for instance, OECD (2003). A detailed discussion can be found in Riesenfeld (1960).
} 
amendments enacted in the ensuing years, this culminated in a failed attempt to adopt a general competition law in the early 1950 s. ${ }^{45}$ This attempt was unsuccessful not least because of a deeply rooted conviction among French politicians that the planification policy was the best way to allocate resources and to support home industries in emerging global markets. ${ }^{46}$ In the words of Fridenson (1997, p. 226):

"In 1950 the French government finally decided not to send to parliament an antitrust bill which Jean Monnet and his Planning Commission had drafted. A majority of French politicians wanted to keep as much interfirm cooperation as possible in times of hardening international competition."

As an, arguably imperfect, substitute, the French government issued a decree stating that: 47

"All concerted actions, agreements, express or implied understandings, or coalitions, in whatever form and for whatever reason, which have as their object or may have as their effect restraint of the free exercise of competition by impeding the reduction of costs or prices or by encouraging an artificial increase in prices."

This decree extended the 1945 price control ordinance and, in fact, reads very much like a modern competition law. ${ }^{48}$ It was not only directed against cartels, but also at restrictive business practices such as resale price maintenance. This provision appeared far less effective in practice, however, which was partly due to two clear exemptions. Exempted were agreements (i) which result from the application of a legislative or regulatory measure, or (ii) which are demonstrated by the parties to have the effect of improving production, or assuring the development of economic progress by means of rationalisation and specialisation. 49

\footnotetext{
${ }^{45}$ See Pace and Seidel (2013).

${ }^{46}$ As remarked by Souam (1998, p. 206): "The idea that economic efficiency is better guaranteed by competitive markets had real difficulty achieving acceptance among policy-makers."

47 This decree, No. 53-704, was passed on August 9, 1953. It was amended to include an abuse of dominance provision ten years later, law No. 63-628.

${ }^{48}$ It has been suggested that this law was heavily inspired by American antitrust legislation, in part because it was generally felt that antitrust policy was an important cause of the success of American enterprises. See Clement (1974).

${ }^{49}$ These exemptions were arranged in Article 59 ter. See Pace and Seidel (2013) and Riesenfeld (1960).
} 
Moreover, the enforcement of this rule was primarily reactive and cases were mostly dealt with on an ad hoc basis. ${ }^{50}$

A more convincing move towards contemporary competition law enforcement took place a few decades later. Partly driven by the international oil crises, France faced a severe economic downturn with high inflation and unemployment during the second half of the 1970s. The response by the government was, however, radically different compared to the crisis years of the 1930s. Competition policy was intensified rather than relaxed and more resources were made available to the newly installed Commission de la Concurrence. ${ }^{51}$ Additionally, France adopted a merger control regime.

This change in direction was reinforced by a reform in 1986, which effectively removed price controls altogether. The 1986 ordinance further transformed the Commission de la Concurrence into the Conseil de la Concurrence. In addition to its advisory task, this new body was given the right to start proceedings and to impose penalties without the Minister of Economy being involved. Moreover, it brought the French competition rules in line with the European ones as laid down in the Treaty of Rome. This ordinance is therefore argued to have been of great symbolic value as it made France one of the first to clearly make its competition policy compatible with the European counterpart. ${ }^{52}$

Some amendments in 1987 allowed for appeals against the authority's decisions at the Cour d'appel de Paris, thereby enhancing the separation between the Economic Ministry and competition law enforcement. The Conseil de la Concurrence was allocated even more power in 2001 when French competition laws were restated and codified in the Nouvelles

\footnotetext{
${ }^{50}$ Also, some commentators have argued that the French government agreed only on the condition that "no one would ever hear about it". See Dumez and Jeunemaître (1996).

${ }^{51}$ This commission effectively replaced the Commission Technique des Ententes; an advisory body that was active since 1953.

${ }^{52}$ See Chapter 10 of Gerber (1998).
} 
Regulations Economique (NRE). ${ }^{53}$ Among other things, it provided more scope for proactive competition law enforcement and allowed for more severe fines. Also, a system of self-reporting was installed that induces those who are acting in breach of competition laws to inform the authority in exchange for a reduction of the antitrust penalty.

The last substantial change took place about a decade ago. In 2009, a new competition authority, the Authorité de la Concurrence, was established. ${ }^{54}$ This independent administrative authority combines the several enforcement tasks that were still allocated among the Conseil de la Concurrence and the Economic Ministry. Important implications of this reform are that it enables the authority to proactively form opinions on (draft) competition legislation and that it has become responsible for merger control. ${ }^{55}$ Like in Germany, however, the Minister of Economy can still intervene in the merger process by requesting an in-depth so-called phase 2 investigation or overturn the authority's decision when public interest demands it. Reasons for the latter include industrial development, employment and the competitiveness of French companies operating in international markets. ${ }^{56}$

\subsection{French Market Competition: From Hierarchy to Coordination?}

The short historical overview of French competition policy sketches a picture of a slow but sure move towards the ordoliberal model of coordinated market competition. Most notably, competition policy has become increasingly independent from state politics. Akin to the German case, however, its origins contain important elements that arguably have a better fit with the hierarchical market tradition. In particular, French competition policy has repeatedly favoured big business over labour.

\footnotetext{
${ }^{53}$ See OECD (2003) and Lachnit (2016).

${ }^{54}$ It was installed on March 2, 2009, by reforming the Conseil de la Concurrence. See the Law of Modernisation of the Economy, No. 2008-776, and the Ordinance of Modernisation of Competition Regulation, No. 2008-1161. 55 See Lasserre (2009).

${ }^{56}$ See Article L. 430-7-1 of the French Commercial Code (Code de Commerce).
} 
Indeed, one characteristic feature of the hierarchical market model is that organization of labour is weak. This was certainly the case in the early years of French competition policy. For instance, right from the beginning, Le Chapelier Law banned strikes and ruled out any association of workers. Unions and other types of cooperation were allowed again after 1864 when the coalition offense of Article 419 was abolished. ${ }^{57}$ In most cases, however, French businesses benefited more from this than did their employees.

In the years directly following World War II, labour was again marginalized. Several "modernization commissions" were installed by the planning board, for example, which brought together representatives of capital and labour as well as planning staff and experts. Yet, it quickly became apparent that the influence of the working class would be very limited. In fact, this cooperative setup enhanced ties between big companies and the French state. As remarked by Michalet (1974):

"The representatives of the workers' unions... have only played a minor role. The Commissions du Plan have contributed largely toward bringing together the state on the one hand and large enterprises on the other."

And although the first actual French competition law was around the corner, the 1953 decree soon appeared ineffective in protecting market competition and, in particular, in mitigating the power of big businesses. ${ }^{58}$ For a significant part this was due to the widely held believe that French firms were too small to be competitive on a global scale. Indeed, the planning board openly favoured: ${ }^{59}$

"...concentration within each sector of industry, larger production units and firms, the adoption of machines and technologies that would make mass

\footnotetext{
${ }^{57}$ See Souam (1998).

${ }^{58}$ As Jenny (1990, p. 150) wrote: "Besides the obvious unwillingness of public authorities to rely on market forces in a competitive environment to achieve efficiency, the system designed in 1953 was largely ineffective because the legal means of the Minister in charge of Economic Affairs were insufficient to dissuade firms from engaging in anticompetitive practices either because they did not care about the warnings that he could issue or because the courts did not handle speedily and effectively the cases which he decided to refer to them."

${ }^{59}$ See Djelic (2001, p. 137)
} 
production possible, and a rationalization of management and production methods."

This positive perspective on industry concentration manifested itself in several ways. First, the French government largely ignored small and medium-sized companies and primarily focused on the creation of national champions. Second, the number of multinational companies active in France substantially increased during the 1960 s. ${ }^{60}$ Third, external growth through merger was actively encouraged. ${ }^{61}$

"...starting in 1965, a tax deduction was offered to any firm willing to merge with another firm. This tax deduction... was applied to all mergers, whether horizontal, vertical, or conglomeral. What is more, the Ministry of Industry, during the sixties and first half of the seventies, directly arranged mergers among the leaders of various key industrial sectors such as steel, computers, glass, etc."

Not surprisingly, France witnessed a large number of mergers in the 1960s and 1970s. In sum, between the Second World War and the second oil crisis in the late 1970s: "...the French authorities were obsessed with increasing the size of firms". 62

The combination of big (diversified, multinational) companies and atomistic, weakly organized, labour makes French market competition primarily compatible with the hierarchical capitalist model, at least until the late 1970s. As mentioned above, however, there was an important competition policy reform in 1977 and this reform pushed France in the direction of the European coordinated market model. For a significant part, this switch was due to the impetus of Prime Minister Raymond Barre. Not only was he a trained economist and former chairman of the European Commission, he had also published on the, at the time relatively novel, ordoliberal philosophy in the 1950s.

\footnotetext{
${ }^{60}$ See Michalet (1974).

61 Jenny (1981, p. 478).

62 Jenny (1981, p. 477).
} 
As mentioned above, the coordinated market model requires a strong and autonomous competition authority. ${ }^{63}$

"...the monopoly office would also have to be made into a strong institution. It would have to have significant enforcement authority so that it effectively could demand compliance, and it would have to have the resources necessary to operate quickly and decisively and to attract and maintain personnel of the highest caliber...and they had to be largely protected from outside political or pecuniary influences."

Regarding resources, these were very limited until 1977. Those who were given the task to enforce French competition laws were few in number, only partly specialized and typically had many other tasks to fulfil. ${ }^{64}$ The establishment of the new Commission de la Concurrence implied more resources and a severe enhancement of French competition law enforcement.

Regarding autonomy, this was de facto absent in decades following World War II as the Economic Ministry was the main enforcer and ultimately had the final say in competition cases. However, the French competition authority became more and more independent since the late 1970s. After a hesitant start in which the Commission de la Concurrence remained primarily an advisory body, a major step towards independence occurred in 1986 with the establishment of the Conseil de la Concurrence. ${ }^{65}$ As Gerber (1998, p. 406) put it:

"...the key was to refashion the main enforcement institution, now called the Conseil de la Concurrence ('Conseil'). Drafters of the legislation were aware that it could achieve its aims only if those making decisions within it were in the position to withstand the deeply-rooted influence of dirigisme. This meant increased independence for the body administrating the law and they thus renamed it to reflect the image of increased independence."

Yet, it was not until a decade ago that French competition law enforcement was put in the hands of a single competition agency; the

\footnotetext{
${ }^{63}$ See Gerber (1998, p. 255).

${ }^{64}$ See Clement (1974).

${ }^{65}$ See Gerber (1998) and Lachnit (2016).
} 
Authorité de la Concurrence. There is little doubt that this organizational reform has strongly supported the independence of the competition authority and consequently can be considered an important step towards the ordoliberal ideal.

This does not mean that the current system is completely immune to government interference, however. Indeed, similar to the German counterpart, the French minister of economic affairs can still intervene in merger processes when such intervention is considered in the public interest. Thus, even though the Economic Ministry undeniably has lost terrain in terms of decision-making power, particularly in cases dealing with anticompetitive conduct, it did not completely vanish from the market competition scene. Specifically, when it comes to competition matters dealing with industry structure, the French state has never been far away.

\section{Concluding Remarks}

On February 6, 2019, the European Commission communicated that it had blocked the proposed merger by the French Alstom and the German Siemens Mobility. The main reason for preventing this merger is that it would result in excessive industry concentration in some signalling markets as well as in the very high-speed train market. The European Commissioner for Competition, Margrethe Vestager, additionally clarified that the companies did not adequately address the Commission's competition concerns. The French economy minister Bruno Le Maire was quick to respond that he, together with the German economy minister Peter Altmaier, will soon put forward a proposal to reform the European competition law system. In particular, this new policy should incentivize European companies to grow and be ready to compete on a global scale. Merkel and Macron have also recently advocated the need for "European Champions" to face the increasing competitive pressure from China and other parts of the world. 
This recent case, on the one hand, illustrates that contemporary European competition policy functions largely like the ordoliberals envisaged. The competition authority independently assessed the proposed merger and concluded that approval would harm the competitive order in the particular markets. On the other hand, the same case also shows that competition policy may be under severe pressure from the state. This paper has shown that this is anything but new. ${ }^{66}$ In both Germany and France, competition policy has been frequently challenged by politicians and big business representatives. One recurring argument is that industrial giants are required to stand the test of competition in international markets.

There is little doubt that today's competition policy in both countries is mainly compatible with the coordinated market model. Yet, when it comes to market structure, we have shown there are some elements that fit more naturally within the hierarchical market tradition. Following the above statement by Jean Monnet, the political response to the European Commission's decision on the Alstom-Siemens merger reveals that France and Germany may indeed have a common interest beyond their differences and geographical boundaries. This common interest, however, need not necessarily be a competitive order safeguarded by a strong competition policy.

\footnotetext{
${ }^{66}$ In this respect, see also the recent study by Dinc and Erel (2013) who find empirical evidence for economic nationalism in European Merger and Acquisitions cases.
} 


\section{References}

Clement, B. (1974), "An Appraisal of French Antitrust Policy, Antitrust Bulletin, 19(3), 587-603;

Dinc, Serdar and Isil Erel (2013), "Economic Nationalism in Mergers and Acquisitions," Journal of Finance, 68(6), 2471-2514;

Djelic, Marie-Laure (2001), "Exporting the American Model: The Postwar Transformation of European Business," Oxford University Press, Oxford;

Dumez, Hervé and Alain Jeunemaître (1996), "The Convergence of Competition Policies in Europe: Internal Dynamics and External Imposition," in: Berger, Suzanne and Ronald Dore (eds.), "National Diversity and Global Capitalism," Cornell University Press, Ithaca;

Fridenson, Patrick (1997), "France: the relatively slow development of big business in the twentieth century," in: Chandler Jr., Alfred D. Franco Amatori and Takashi Hikino (eds.), "Big Business and the Wealth of Nations," Cambridge University Press, Cambridge;

Gerber, David J. (1998), "Law and Competition in Twentieth-Century Europe: Protecting Prometheus," Oxford University Press, Oxford;

Hall, Peter A. and David Soskice (eds.) (2001), "Varieties of Capitalism: The Institutional Foundations of Comparative Advantage," Oxford University Press, Oxford;

Klees, Andreas M. (2006), "Breaking the Habits: The German Competition Law after the $7^{\text {th }}$ Amendment to the Act against Restraints of Competition (GWB)," German Law Journal, 7(4), 399-419;

Lachnit, Eva S. (2016), "Alternative Enforcement of Competition Law," Ph.D. Dissertation, Eleven International Publishing, The Hague;

Lasserre, Bruno (2009), "The new French competition law enforcement regime," Competition Law International, 5(3), 15-20; 
Jenny, Frédéric (1990), "French Competition Policy in Perspective," in: Comanor, William S., Ken George, Alexis Jacquemin, Frédéric Jenny, Erhard Kantzenbach, Janusz A. Ordover and Leonard Waverman (1990), "Competition Policy in Europe and North America," Harwood Academic Publishers $\mathrm{GmbH}$, New York;

Jenny, Frédéric (1981), "From Price Controls to Competition Policy in France: the Uneasy Alliance of Economical and Political Considerations," Annals of Public and Cooperative Economics, 52(4), 477-490;

Martin, Stephen (2010), "Industrial Organization in Context," Oxford University Press, Oxford;

McGowan, Lee (2010), "The Antitrust Revolution in Europe: Exploring the European Commission's Cartel Policy," Edward Elgar Publishing, Cheltenham;

Neumann, Manfred (1998), "The Evolution of Cartel Policy in Germany," in: Martin, Stephen (ed.), "Competition Policies in Europe," Elsevier, North-Holland, the Netherlands;

OECD (2003), "Country Studies: France - The Role of Competition Policy in Regulatory Reform," 1-54;

Pace, Lorenzo F. (2007), "European Antitrust Law: Prohibitions, Merger Control and Procedures," Edward Elgar, Cheltenham: United Kingdom;

Pace, Lorenzo F. and Katja Seidel (2013), "The Drafting and the Role of Regulation 17: A Fragile Balance," in: Patel, Kiran K. and Heike Schweitzer (eds.), "The Historical Foundations of EU Competition Law," Oxford University Press, Oxford;

Poli, Eleonora (2015), "Antitrust Institutions and Policies in the Globalising Economy," Palgrave Macmillan, London;

Schwartz, Ivo E. (1957), "Antitrust Legislation and Policy in Germany - A Comparative Study," University of Pennsylvania Law Review, 105 (5), 617-690; 
Souam, Saïd (1998), "French Competition Policy," in: Martin, Stephen (ed.), "Competition Policies in Europe," Elsevier, North-Holland, the Netherlands;

Resch, Andreas (2005), "Phases of Competition Policy in Europe," Working Paper, AY0504, Institute of European Studies, University of California, Berkeley;

Riesenfeld, Stefan A. (1962), "Antitrust Laws in the European Economic Community," California Law Review, 50(3), 459-481;

Riesenfeld, Stefan A. (1960), "The Legal Protection of Competition in France," California Law Review, 48(4), 574-595;

Schneider, Ben R. (2009), "Hierarchical Market Economies and Varieties of Capitalism in Latin America," Journal of Latin America Studies, 41(3), 553575;

Schneider, Ben R. and David Soskice (2009), "Inequality in Developed Countries and Latin America: Coordinated, Liberal and Hierarchical Systems," Economy and Society, 38(1), 17-52;

Verloop, Peter and Valérie Landes (eds.) (2003), "Merger Control in Europe: EU, Members States and Accession States," $4^{\text {th }}$ edition, Kluwer Law International, The Hague;

Withley, Richard (1999), "Divergent Capitalisms: The Social Structuring and Change of Business Systems," Oxford University Press, Oxford. 